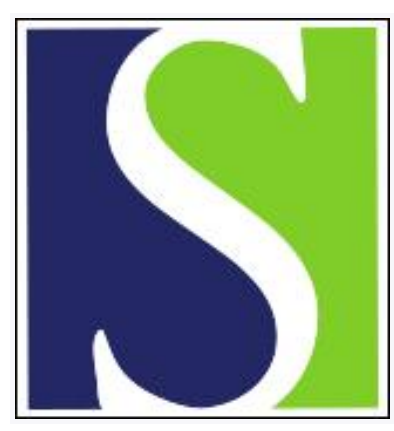

Scand J Work Environ Health 1995;21(6):487-493

https://doi.org/10.5271/sjweh.65

Issue date: Dec 1995

Occurrence of self-reported asthma among Swedish bakers by Brisman SJ, Järvholm BG

Key terms: asthma incidence; bakers' asthma; cohort study; occupational asthma

This article in PubMed: www.ncbi.nlm.nih.gov/pubmed/8824755

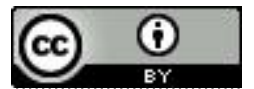




\title{
Occurrence of self-reported asthma among Swedish bakers
}

\author{
by $S$ Jonas Brisman, $M D,{ }^{1}$ Bengt G Järvholm, $M D^{1}$
}

\begin{abstract}
Brisman SJ, Järvholm BG. Occurrence of self-reported asthma among Swedish bakers. Scand J Work Environ Health 1995;21:487-93.

Objective The purpose of this study was to estimate the risk of bakers to develop asthma.

Methods A retrospective cohort study was performed among persons trained as bakers in Swedish trade schools in 1959-1989 ( $\mathrm{N}=2923)$. One group of referents (I) comprised persons who followed another program in the trade schools $(\mathrm{N}=1258)$, and another (II) was randomly selected from the population register $(\mathrm{N}=1258)$. A questionnaire on physician-diagnosed asthma, year of onset of asthma, asthma-like symptoms, consumption of antiasthmatic drugs, change of work due to asthma, familial atopy, and work history was mailed to all the participants. The incidence rates for persons trained as bakers were estimated separately for time as a baker and time in other occupations.

Results The response rate was about $75 \%$ in all three groups. There were no differences in the prevalence of asthma, asthma-like symptoms, consumption of antiasthmatic drugs, or familial atopy between the groups. Of the bakers, $2.5 \%$ had changed work due to asthma, significantly more than the referents $(1.1 \%$ of reference groups I and II had changed, $\mathrm{P}<0.05$ ). The incidence rate for asthma among the men not working as bakers was $0.9-1.9$ cases per 1000 person-years; male bakers had an incidence rate of 3.0. The relative risk for male bakers compared with all the referents was 1.8 (95\% confidence interval 1.3-2.6). Women had an incidence rate of 2.3-3.0 cases per 1000 person-years, and there was no increased relative risk during work as a baker.

Conclusions Male Swedish bakers, mainly those working during the 1970s and 1980s, have an approximately doubled risk to develop asthma.
\end{abstract}

Key terms asthma incidence, bakers' asthma, cohort study, occupational.

Asthma is a well-known effect of exposure to flour dust and its contaminants among bakers. Bakers' asthma is essentially regarded as an allergic reaction mediated by immunoglobulin $(\mathrm{Ig}) \mathrm{E}$ antibodies against airborne allergens present in bakeries (1).

Several cross-sectional studies reporting prevalences of asthma or work-related respiratory symptoms have been published. Reported cumulative prevalences of asthma or respiratory symptoms among bakers have varied considerably. In pre-World War II studies, there were prevalences between $3.1-44 \%$, as reported by Thiel (2).

In later studies Wallenstein et al (3) reported an asthma prevalence of 35\%, Järvinen et al (4) gave an asthma prevalence of $9 \%$ ( $6 \%$ was regarded as "flour allergic"), Thiel \& Ulmer (5) reported 7\% for "flour-induced" asthma, Pritchard et al's (6) prevalence was 5\% for "workrelated asthma" and 19\% for "work-affected chest," and Musk et al (1) reported $13 \%$ for work-related chest problems. In another study (7) $4.9 \%$ of Italian bakers and pasty makers reported "work-related asthma". Six per- cent of British bakers, flour packers, and millers reported "work-related chest symptoms" (8).

Some register-based studies have assessed the incidence rate for occupational asthma among bakers. The Swedish occupational disease register reported an incidence rate of occupational asthma of 0.80 per 1000 in the years $1984-1986$ for bakers (9). (This register is based on cases reported for workers' compensation from the social security system.) The incidence rate among British bakers was estimated to be 0.41 per 1000 in 1989 (10). In a British regional occupational asthma surveillance scheme the mean incidence of occupational asthma among bakers during 1989-1991 was 0.45 cases per 1000, 95\% confidence interval (95\% CI) $0.21-0.82$ (11). The Finnish Register of Occupational Diseases reported an incidence of 4 cases per 1000 bakers in 1990 (12).

Our objective was to perform a longitudinal study to estimate the risk to develop asthma in relation to occupational exposure to dust in bakeries. We analyzed the

1 Institute of Internal Medicine, Section of Occupational Medicine, Göteborg University, Göteborg, Sweden.

Reprint requests to: Dr SJ Brisman, Institute of Internal Medicine, Section of Occupational Medicine, Göteborg University, St Sigfridsgatan 85, S-412 66 Göteborg, Sweden. 
relationship between new cases of asthma and work as a baker (ie, the asthma incidence rate) and compared it with the incidence rate of referents.

\section{Subjects and methods}

\section{Study design and subjects}

The study was a retrospective cohort investigation using a self-administered postal questionnaire to register the outcome. The subjects comprised persons born in 1943 1972 and found in the records of all bakery classes in Swedish trade schools from 1959 to 1989. These persons usually followed the bakery program for two years, beginning at 16 years of age. All persons who had completed the last year of the program according to the records were eligible for the study. In this way 3030 persons, trained to become bakers, were identified.

Two reference groups were used in the study. One group (reference group I) comprised persons born in 1943-1972, who went to the same trade schools during the same period as the bakers, but followed another program. They were mostly trained in other trades of the food processing industry, such as butcher, cook, or brewery or dairy worker. For every 10 bakers, four referents from the same school and year were selected at random. The total number of subjects in reference group I was 1299.

Ninety-five bakers and referents (I) were not found in the population register in 1992 and thus were excluded from the study. Of these 12 were dead, 14 had emigrated, 3 had changed address by the time of the study, 3 had prohibited the register to give their address, and 63 were not located in the register, probably because of changed personal identification numbers or emigration without notice to authorities. After these exclusions 2923 bakers and 1258 referents (I) remained.

A second reference group (II) was selected at random from the Swedish population register, stratified for gender and 10-year birth class and also comprising 1258 persons.

The study was approved by the Committee of Ethics of the Göteborg University and by the Data Inspectorate.

\section{Questionnaire}

A self-administered questionnaire was mailed to all 5439 participants in late 1992 . The respiratory part of the questionnaire included questions concerning the occurrence of asthma, symptoms from the lower airways, use of antiasthmatic drugs, smoking habits, change of work due to asthma, and asthma among next-of-kin.

The questions about asthma were: "Do you have or have you had asthma?" (Question $1=Q 1$ ). If the question received an affirmative answer, the following questions were asked: "How old were you when the asthma started?" (Q2A), "Have you had asthma in the last 12 months?" (Q2B), "If you have had asthma, but no asthmatic symptoms in the last 12 months, in what year did you last have asthmatic symptoms" (Q2C), "Has a doctor diagnosed your asthma?" (Q3). Asthma was defined as a positive answer to the last question.

Questions relating to asthma-like symptoms were the following: "Have you ever had wheezing in your chest?" (Q4), "Have you ever been awakened at night by shortness of breath?" (Q5). If the answer was "yes" to either of these two questions, the following question was asked: "Is your breathing normal between times with shortness of breath or wheezing in your chest?" (Q6). The next questions were "Have you ever had breathlessness when in contact with animals, feathers, eiderdowns (including pillows and quilts) or house dust?" (Q7), "Do you use any antiasthmatic drug (permanently or when necessary)?" (Q8), and "Do you usually bring up phlegm, or do you have phlegm in your chest that is difficult to bring up?" (Q9).

The subjects were defined as nonsmokers if they had smoked more seldom than once every week. Smokers were defined as subjects smoking at least once a week or if they had given up smoking during the last year. They were also asked in what year they had started smoking. Ex-smokers were defined as subjects who had given up smoking more than one year ago. They were also asked when they started and when they gave up smoking.

The question concerning asthma among next-of-kin was "Have any of your parents or siblings suffered from asthma?" (Q21A). The question concerning change of work was worded: "Have you ever changed jobs due to asthma?" (Q20A).

Questionnaires on occupational history were administered together with the main questionnaire. Bakers were asked during what years they had worked in bakeries.

\section{Nonrespondent study}

Altogether 5439 questionnaires were sent. The response rates after two reminders were bakers 2226 of $2923=$ $76.4 \%$, referents I 931 of $1258=74.0 \%$, referents II 930 of $1258=73.9 \%$. In order to study some determinants for the nonrespondents, random samples (100 bakers, 50 referents I and 50 referents II) were chosen to be interviewed by phone by one of us (JB). Of the selected 200 persons, 131 were found in the telephone directory, and 111 were interviewed. They were questioned with an abbreviated questionnaire asking for the occurrence of asthma, its temporal aspect, asthma among next-of-kin, and smoking habits. The bakers were also asked basic questions on their working history and if they had changed jobs due to asthma.

Fifty-six bakers were interviewed by telephone, another four were detected as misclassified (they had either 
not terminated their training as bakers or they had never been trained as such at all). Twenty-seven referents I and 24 referents II answered the questions by telephone.

\section{Reliability}

In order to study the reliability of question Q3 ("Has a doctor diagnosed your asthma?"), a second, identical questionnaire was mailed to two random samples of persons who had answered the first questionnaire in the first round, without any reminder. Sample I comprised 100 persons from all three groups (bakers and referents I and II) who reported having asthma diagnosed by a physician. Sample II included 100 persons from all three groups who denied having asthma diagnosed by a physician. The second questionnaire was sent out five months after the first one.

The response rates of the two samples were 72 and $74 \%$, respectively. The agreement between the discrete variables was estimated by the kappa coefficient (13). The kappa coefficient of the question concerning physician-diagnosed asthma (Q3) was 0.90.

The reliability of the temporal aspect of the onset of asthma (question $2 \mathrm{~A}$ in the questionnaire) was also studied. In the reliability testing, there were 65 persons of sample I who admitted having a physician's diagnosis of asthma on both occasions. Six of these persons (9.2\%) did not answer question $2 \mathrm{~A}$ on the second occasion. Twenty-eight persons (43.1\%) gave identical answers to question $2 \mathrm{~A}$ on the two occasions, the answers of 19 persons $(29.2 \%)$ differed by one year, for seven persons $(10.8 \%)$ it differed by two years, for three persons (4.6\%) three years, and for one person each $(1.5 \%)$ the difference was four and eight years.

\section{Data analysis}

A comparison of prevalences was performed with the chi-square test. A comparison of the means was performed with a t-test. Incidence rates were calculated as the number of new cases of asthma per person-years under observation. The person-years were calculated for the bakers and referents I from the year they left the trade school program. The observation period was between 1961 and 1992. The population referents (II) contributed with person-years from 18 years of age (ie, the age at which most bakers left the school). If asthma was reported before 18 years of age or if the starting year of the disease was unknown, then the subject was excluded from the incidence study. For the bakers, the incidence rate was calculated separately for time as a baker and time in other occupations.

Incidence rate ratios were calculated and are referred to as "relative risks"; $95 \%$ confidence intervals $(95 \% \mathrm{CI})$ were calculated with the test-based method (14).

\section{Results}

Of the 2226 bakers that answered the postal questionnaire, $73.9 \%(\mathrm{~N}=1644)$ had worked as a baker after leaving school, $25.1 \%(\mathrm{~N}=558)$ had never worked as a baker, and $1.0 \%$ (24) did not state their work history.

The mean ages of the respondents and nonrespondents are presented in table 1; the smoking habits are also given for the respondents. For the nonrespondents interviewed by telephone, $33.9 \%$ of the bakers were smokers, $16.1 \%$ were ex-smokers, and $50.0 \%$ were non-

Table 1. Age and smoking habits (only respondents) of the subjects in 1992.

\begin{tabular}{|c|c|c|c|c|c|c|c|c|c|}
\hline \multirow[t]{3}{*}{ Group } & \multicolumn{6}{|c|}{ Respondents } & \multicolumn{3}{|c|}{ Nonrespondents } \\
\hline & \multirow[t]{2}{*}{$\mathrm{N}$} & \multicolumn{2}{|c|}{ Age (years) } & \multicolumn{3}{|c|}{ Smoking habits (\%) } & \multirow[t]{2}{*}{$\mathrm{N}$} & \multicolumn{2}{|c|}{ Age (years) } \\
\hline & & Mean & $\mathrm{SD}$ & $\begin{array}{l}\text { Current } \\
\text { smoker }\end{array}$ & $\begin{array}{c}\text { Ex- } \\
\text { smoker }\end{array}$ & $\begin{array}{l}\text { Never } \\
\text { smoker }\end{array}$ & & Mean & $\mathrm{SD}$ \\
\hline \multicolumn{10}{|l|}{ Bakers } \\
\hline $\begin{array}{l}\text { Men } \\
\text { Women }\end{array}$ & $\begin{array}{r}1280 \\
946\end{array}$ & $\begin{array}{l}31.4 \\
26.5\end{array}$ & $\begin{array}{l}5.2 \\
8.3\end{array}$ & $\begin{array}{l}37.6 \\
40.4\end{array}$ & $\begin{array}{l}15.0 \\
10.7\end{array}$ & $\begin{array}{l}47.3 \\
49.1\end{array}$ & $\begin{array}{l}484 \\
213\end{array}$ & $\begin{array}{l}31.6 \\
27.8\end{array}$ & $\begin{array}{l}7.9 \\
5.9\end{array}$ \\
\hline \multicolumn{10}{|c|}{ Ever worked as baker } \\
\hline \multicolumn{10}{|l|}{ Yes } \\
\hline $\begin{array}{l}\text { Men } \\
\text { Women }\end{array}$ & $\begin{array}{r}1029 \\
615\end{array}$ & $\begin{array}{l}31.6 \\
26.5\end{array}$ & $\begin{array}{l}8.6 \\
5.0\end{array}$ & $\begin{array}{l}36.7 \\
35.1\end{array}$ & $\begin{array}{l}15.2 \\
10.5\end{array}$ & $\begin{array}{l}48.1 \\
53.6\end{array}$ & - & . & . \\
\hline \multicolumn{10}{|l|}{ No } \\
\hline $\begin{array}{l}\text { Men } \\
\text { Women }\end{array}$ & $\begin{array}{l}235 \\
323\end{array}$ & $\begin{array}{l}30.6 \\
26.3\end{array}$ & $\begin{array}{l}7.3 \\
5.4\end{array}$ & $\begin{array}{l}41.4 \\
48.2\end{array}$ & $\begin{array}{l}16.7 \\
11.3\end{array}$ & $\begin{array}{l}41.9 \\
40.5\end{array}$ & - & . & . \\
\hline \multicolumn{10}{|l|}{ Referents I } \\
\hline $\begin{array}{l}\text { Men } \\
\text { Women }\end{array}$ & $\begin{array}{l}547 \\
384\end{array}$ & $\begin{array}{l}31.3 \\
28.4\end{array}$ & $\begin{array}{l}8.6 \\
6.5\end{array}$ & $\begin{array}{l}43.8 \\
41.8\end{array}$ & $\begin{array}{l}15.3 \\
14.8\end{array}$ & $\begin{array}{l}40.9 \\
43.4\end{array}$ & $\begin{array}{l}225 \\
102\end{array}$ & $\begin{array}{l}30.0 \\
28.2\end{array}$ & $\begin{array}{l}7.7 \\
6.2\end{array}$ \\
\hline \multicolumn{10}{|l|}{ Referents II } \\
\hline $\begin{array}{l}\text { Men } \\
\text { Women }\end{array}$ & $\begin{array}{l}537 \\
393\end{array}$ & $\begin{array}{l}31.7 \\
27.8\end{array}$ & $\begin{array}{l}8.3 \\
6.3\end{array}$ & $\begin{array}{l}36.1 \\
37.5\end{array}$ & $\begin{array}{l}16.1 \\
12.3\end{array}$ & $\begin{array}{l}47.8 \\
50.2\end{array}$ & $\begin{array}{r}228 \\
99\end{array}$ & $\begin{array}{l}32.8 \\
27.1\end{array}$ & $\begin{array}{l}8.8 \\
5.5\end{array}$ \\
\hline
\end{tabular}


Table 2. Cumulative prevalence (as percentage) of asthma, asthmalike symptoms, antiasthmatic drugs, family history of asthma, and change of job due to asthma. One-year prevalence figures within parentheses (ie, asthmatics with symptoms in 1992).

\begin{tabular}{|c|c|c|c|c|c|}
\hline & & \multicolumn{2}{|c|}{ Bakers } & \multirow{3}{*}{$\begin{array}{l}\text { Referents } \mid \\
(N=931)\end{array}$} & \multirow{3}{*}{$\begin{array}{c}\text { Referents II } \\
(N=930)\end{array}$} \\
\hline & & \multicolumn{2}{|c|}{ Ever worked as baker } & & \\
\hline & & Yes $(N=1644)$ & No $(N=558)$ & & \\
\hline Q1. & Asthma ever & $7.0(4.4)$ & $7.9(5.7)$ & $7.7(4.5)$ & $9.0(5.8)$ \\
\hline Q3. & Asthma diagnosed by a physician & $5.7(3.6)$ & $5.7(4.5)$ & $6.4(4.0)$ & $7.8(4.8)$ \\
\hline Q4. & Wheeze ever & 20.0 & 23.3 & 23.9 & 26.6 \\
\hline Q5. & Wakened at night by shortness of breath & 9.0 & 9.9 & 9.0 & 11.1 \\
\hline Q6. & Normal breathing in between ${ }^{\mathrm{a}}$ & 20.2 & 20.9 & 22.1 & 23.6 \\
\hline & Breathlessness with animals, feathers, etc. & 8.6 & 8.8 & 11.9 & 11.2 \\
\hline Q8. & Antiasthmatic drugs & 5.8 & 7.3 & 7.4 & 9.0 \\
\hline Q21A. & Family history of asthma & 17.3 & 17.6 & 15.9 & 18.1 \\
\hline Q20A. & Changed job due to asthma & 2.5 & 0.9 & 1.1 & 1.1 \\
\hline
\end{tabular}

a Prevalence calculated as the proportion of subjects answering this question affirmatively in relation to the number of subjects answering affirmatively to at least one of the two preceding questions $(04,05)$.

smokers. For reference group I the corresponding figures were $37.0,14.8$, and $48.2 \%$, respectively, and for reference group II they were $29.2,20.8$, and $50.0 \%$, respectively. The smoking habits were similar between the persons trained as a baker, but who had never worked as such, and reference group I. They were also similar between persons who had worked as a baker and reference group II. In general, persons answering by telephone smoked less frequently than those answering by mail, but the former group also had a slightly higher proportion of ex-smokers among the bakers and reference group II.

The prevalences of asthma, asthma-like symptoms, familial atopy, and change of work due to asthma are shown in table 2 for the postal questionnaire respondents. Significantly more persons who had ever worked as a baker had changed jobs due to asthma compared with persons who had not worked as a baker after finishing school $\left(X^{2}=4.45, P<0.05\right)$, and also compared with the two reference groups $\left(\mathrm{X}^{2}=6.0, \mathrm{P}<0.05\right)$. There were no statistically significant differences in the other prevalences between the groups. The cumulative prevalence of asthma with onset before the age of 16 years was $3.0 \%$ for the bakers compared with $3.5 \%$ for reference group I and $3.9 \%$ for reference group II. These differences were not statistically different. The mean time between start of work as a baker and onset of asthma was 6.5 (range $0-25$ ) years.
The asthma prevalences of the telephone respondents are shown in table 3 . The numbers were small, but for all three groups there was a tendency for more self-reported asthma and less asthma in the family than among the mail respondents.

The incidence rates for asthma among the bakers and the referents are given in table 4 . The men not working as a baker had incidence rates of $0.9-1.9$ cases per 1000 person-years, whereas the rate for male bakers was 3.0 , that for women not working as a baker was $2.3-3.0$, and that for female bakers was 2.9 .

Relative risks and $95 \%$ confidence intervals are presented in table 5 . There was a significantly increased relative risk for asthma among the male bakers when

Table 3. Cumulative prevalence (as percentage) of asthma and family history of astma in a telephone interview of nonrespondents. For the bakers, also change of job due to asthma and ever worked as baker or not (as percentage).

\begin{tabular}{|c|c|c|c|c|}
\hline & & $\begin{array}{c}\text { Bakers } \\
(N=56)\end{array}$ & $\begin{array}{l}\text { Referents I } \\
(\mathrm{N}=27)\end{array}$ & $\begin{array}{l}\text { Referents II } \\
\quad(N=24)\end{array}$ \\
\hline Q1. & Asthma ever & 14.3 & 22.2 & 12.5 \\
\hline Q3. & $\begin{array}{l}\text { Asthma diagnosed } \\
\text { by a physician }\end{array}$ & 10.7 & 11.1 & 12.5 \\
\hline Q21A. & $\begin{array}{l}\text { Family history } \\
\text { of asthma }\end{array}$ & 14.5 & 7.4 & 8.7 \\
\hline Q20A. & $\begin{array}{l}\text { Changed job due } \\
\text { to asthma }\end{array}$ & 1.8 & & \\
\hline \multicolumn{2}{|c|}{ Ever worked as baker } & 82.1 & & \\
\hline
\end{tabular}

Table 4. Incidence rates for asthma among the bakers and referents. Incidence rates in number of cases per 1000 person-years.

\begin{tabular}{|c|c|c|c|c|c|c|c|c|}
\hline & \multicolumn{8}{|c|}{ Incidence rate } \\
\hline & \multicolumn{4}{|c|}{ Bakers } & \multicolumn{2}{|c|}{ Referents I } & \multicolumn{2}{|c|}{ Referents II } \\
\hline & \multicolumn{2}{|c|}{$\begin{array}{l}\text { When working } \\
\text { as baker }\end{array}$} & \multicolumn{2}{|c|}{$\begin{array}{c}\text { When in } \\
\text { other occupation }\end{array}$} & \multirow{2}{*}{ Incidence } & \multirow{2}{*}{$\begin{array}{c}\text { Number } \\
\text { of asthma } \\
\text { cases }\end{array}$} & \multirow[t]{2}{*}{ Incidence } & \multirow{2}{*}{$\begin{array}{l}\text { Number } \\
\text { of asthma } \\
\text { cases }\end{array}$} \\
\hline & Incidence & $\begin{array}{c}\text { Number } \\
\text { of asthma } \\
\text { cases }\end{array}$ & Incidence & $\begin{array}{l}\text { Number } \\
\text { of asthma } \\
\text { cases }\end{array}$ & & & & \\
\hline $\begin{array}{l}\text { Men } \\
\text { Women }\end{array}$ & $\begin{array}{l}3.0 \\
2.9\end{array}$ & $\begin{array}{r}22 \\
8\end{array}$ & $\begin{array}{l}0.9 \\
2.3\end{array}$ & $\begin{array}{r}9 \\
12\end{array}$ & $\begin{array}{l}1.1 \\
2.9\end{array}$ & $\begin{array}{r}8 \\
12\end{array}$ & $\begin{array}{l}1.9 \\
3.0\end{array}$ & $\begin{array}{l}14 \\
12\end{array}$ \\
\hline
\end{tabular}


working as a baker, compared with time in other occupations or compared with reference group I (table 4). We also combined the three comparison groups (bakers in other occupations and reference groups I and II) and calculated the relative risks for bakers' developing asthma during baker work compared with this combined comparison group. For the men the risk was 1.8 (95\% CI 1.3-2.6), and for the women it was 1.1 (95\% CI $0.5-2.3)$.

\section{Discussion}

In spite of intense discussion over the years, there is no generally accepted definition of asthma. Different operational definitions have been proposed for epidemiologic use. One option is to combine answers from self-administered questionnaires with clinical findings (15). Another option is to rely on questionnaire data only (16). These options were reviewed by Torén et al (17). The responses to the questions "Have you ever had asthma?" and "Has a physician diagnosed your asthma?" were compared with a clinical diagnosis. The sensitivity varied between studies with a range of 48-100\%; in most studies it was between 56 and $88 \%$. However, the specificity was high, especially for the question about "physician-diagnosed asthma" (specificity $\geq 99 \%$ ).

In order to estimate the asthma incidence rate we had to study a considerable number of bakers. Such a study was possible only by using a self-administered questionnaire. It was important to have a high specificity since false-positive asthma cases would underestimate a true association between exposure and incidence. The reliability of the most important question (physician-diagnosed asthma) was estimated and showed an excellent kappa value. The time of onset of asthma is also important when incidence rates are being calculated. The reliability of the question "How old were you when the asthma started?" was also good, and therefore this information is valid and can be used for calculating incidence rates.

The substantial variation in cross-sectional prevalences of asthma or work-related respiratory symptoms in earlier studies may be due to differences in exposure and diagnostic definitions, but also due to selection; affected workers are more or less forced to leave exposure. Although this study was designed to minimize such bias, there may have been selection bias operating, such as the selection of persons without childhood asthma into school bakery programs. Data of asthma prevalence with the onset before 16 years of age does not support such a selection; there was no difference between the bakers and the referents. The reported cumulative prevalences of asthma before the age of 16 years was low (3-4\%) compared with the high prevalence of asthmatic symp-
Table 5. Relative risk of asthma for bakers during work as a baker, compared with time in other occupations and with respect to referents I and $\mathrm{II}(95 \% \mathrm{Cl}=95 \%$ confidence interval)

\begin{tabular}{lrrrrrr}
\hline Comparison group & \multicolumn{2}{c}{ Men } & & \multicolumn{2}{c}{ Women } \\
\cline { 2 - 3 } & Relative & $95 \% \mathrm{Cl}$ & & $\begin{array}{c}\text { Relative } \\
\text { risk } \\
\text { risk }\end{array}$ & $95 \% \mathrm{Cl}$ \\
\hline When in other occupation & 3.3 & $1.6-6.7$ & & 1.3 & $0.51-3.1$ \\
Referents I & 2.7 & $1.3-6.0$ & & 1.0 & $0.50-2.0$ \\
Referents II & 1.6 & $0.82-3.1$ & & 0.96 & $0.40-2.3$ \\
\hline
\end{tabular}

toms, often above $10 \%$, reported for children (18). This finding might suggest that adults have forgotten asthmatic symptoms in childhood or adolescence, and, if so, selection bias into work as a baker could exist if persons going to bakery programs remembered earlier asthrnatic symptoms to a less degree than referents. However, this possibility seems very improbable, nor is there any indication of a less frequent familial history of asthma among bakers. The similar incidence rates for the reference groups and the bakers working in other occupations also makes such a bias improbable.

Diagnostic bias, such as the "over-diagnosing" of asthma among bakers with respiratory symptoms compared with among referents was possible in this study. Therefore, we calculated the proportion of persons diagnosed as asthmatics with onset from 18 years of age or later for all persons reporting asthma-like symptoms among the persons who had worked as bakers and among the two reference groups. There were no differences between the groups; for example, the percentage of persons with physician-diagnosed asthma among those reporting wheezing was $14.0,12.2$ and $13.0 \%$ for the bakers, reference group I and reference group II, respectively. Any diagnostic bias should also be diminished by our asking for the persons' own opinion of when their asthma started, and not the year of a physician's diagnosis.

Another type of bias could have been introduced if the bakers were prone to ascribe the onset of asthma falsely to time with work as a baker. There are two indicators that this bias was not operating. First, the asthma incidence for the women was about the same regardless of exposure, and it is improbable that the men and women should behave differently in relation to this "time of onset" bias. Second, the good reliability of the question on onset of asthma was also somewhat against the "time of onset" bias being of any importance. To validate the questionnaire, we are currently performing a clinical study of bakers with self-reported asthma and referents.

The nonrespondent study indicated that nonrespondents tend to report more asthma than respondents. The nonrespondents had also worked as a baker more frequently. The data on familial history of asthma among the nonrespondents are conflicting, but may be a random result.

Scand J Work Environ Health 1995, vol 21, no 6 
The incidence rate for the men during time as a baker was 3.0 cases per 1000 person-years, compared with $0.9-1.9$ cases for the referents. This finding indicates an asthma incidence caused by work as a baker of $1-2$ cases per 1000 person-years. This incidence is somewhat higher than that reported in Swedish and British registerbased studies $(9,10,11)$, but somewhat lower than the reported Finnish incidence (12). An explanation for this discrepancy can be the voluntary participation in the British surveillance in contrast to the mandatory reports in Finland.

Among the women the incidence rate was 2.3-3.0 cases per 1000 person-years, but there was no increased relative risk for asthma. The higher incidence rate for the women agrees with reports of a greater incidence for women than men after the age of 20 years (16). Age and smoking status may affect the asthma incidence. To evaluate this possibility, we estimated the incidence rate in two age classes ( $\leq 35$ and $>35$ years of age) and in two smoking classes (current and ex-smokers as one class and never smokers as the other). There were fewer than 10 cases of asthma in 29 of the 32 formed cells, and the incidence rates showed substantial variation without any clear trends. However, the relative risk for asthma onset during work as a baker among the ever smokers compared with the never smokers was 1.6 for the men and 1.3 for the women. The corresponding $95 \%$ confidence interval comprised unity. Furthermore, age was an improbable confounder in this study, as the different groups had similar age distributions (table 1).

The explanation for the absence of an increased risk among the women can be that female bakers are less exposed than male bakers. The female bakers were significantly younger than their male counterparts (mean age 26.4 versus 31.6 years) and therefore had a shorter duration of exposure. After visits to bakeries we also have the impression that female bakers do not perform the most dust-exposed tasks.

In order to determine whether the incidence of asth$\mathrm{ma}$ is higher in the early years of employment, we calculated the incidence rate in the first two years of employment. It was 3.8 for the men ( 7 cases) and 0.9 for the women ( 1 case); thus it was about the same incidence as during the total observation period. Our observed latency time for asthma (time between first employment and reported onset of asthma) of 6.4 years is in keeping with the latency of 4.2 years in the cross-sectional study of Järvinen et al (4). However, the material of our study, with the low average age and short employment time, was probably not ideal for studying latency time.

Only a few studies have measured the incidence of asthma in occupational settings. Davies et al (19) reported an incidence of $2 \%$ during the first year of exposure among laboratory animals. Torén et al (20) measured the incidence of self-reported, but not physician- diagnosed asthma among paper mill workers. The incidence rate ranged from 1.1 per 1000 person-years among the low-exposed workers to 1.5 among the mediumexposed and to 2.3 among high-exposed.

If the analysis of this study had been confined to the comparison of prevalences, it would have only showed the increased frequency of change of work due to asthma, but the incidence analysis also revealed the increased asthma incidence among male bakers during occupational exposure. We regard the incidence analysis as a more sensitive tool for detecting a true association between occupational exposure and asthma, and we propose that the incidence rate be estimated more frequently in etiologic studies.

\section{Acknowledgments}

The study was supported by the Swedish Work Environment Fund.

Mr Daniel Klein is thanked for his computer assistance and Ms Maria Edvardson for her word-processing.

\section{References}

1. Musk A, Venables KM, Crook B, Nunn AJ, Hawkin R, Crook GDW et al. Respiratory symptoms, lung function and sensitization to flour in a British bakery. Br J Ind Med 1989;46:63642.

2. Thiel H. Bakers' asthma: epidemiological and clinical findings - needs for prospective studies. In: Kerr JW, Gaderton MA, editors. XI International congress of allergy and clinical immunology. London: McMillan Press, 1983:429-33.

3. Wallenstein G, Rebohle E, Bergman I. Allergische Atemtrakterkrankungen bei Bäckern und Müllern. Detsch Gesundheitswes 1979;34:2577-80.

4. Järvinen K, Pirilä V, Björksten F, Keskinen H, Lehtinen M, Stubb S. Unsuitability of bakery work for a person with atopy. Ann Allergy 1979;42:192-5.

5. Thiel H, Ulmer WT. Bakers' asthma: development and possibility for treatment. Chest 1980;70:400s-5s.

6. Pritchard MG, Ryan G, Musk A. Wheat flour sensitisation and airways disease in urban bakers. Br J Ind Med 1984;41:45054.

7. De Zotti R, Larese F, Bovenzi M, Negro C, Molinari S. Allergic airway disease in Italian bakers and pastry makers. Occup Environ Med 1994;51:548_52.

8. Cullinan P, Lowson D, Nieuwenhuijsen MJ, Sandiford C, Tee $\mathrm{RD}$, Venables KM, et al. Work related symptoms, sensitisation, and estimated exposure in workers not previously exposed to flour. Occup Environ Med 1994;51:579-83.

9. Malmberg P. Yrken/arbetsmiljöer med hög sjuklighet i respirationsorganen [Occupations with increased morbidity due to respiratory diseases]. Stockholm: Arbetarskyddsverket, 1990. Arbete och Hälsa 1990:6.

10. Meredith SK, Taylor VM, McDonald JC. Occupational respi- 
ratory disease in the United Kingdom 1989: a report to the British Thoracic Society and the Society of Occupational Medicine by the SWORD project group. Br J Ind Med 1991;48: 292-8.

11. Gannon PFG, Burge PS. The SHIELD scheme in the West Midlands Region, United Kingdom. Br J Ind Med 1993;50: $791-6$.

12. Nordman H. Occupational asthma - time for prevention. Scand J Work Environ Health 1994;20 special issue:10815 .

13. Cohen J. A coefficient of agreement for nominal scales. Educ Psychol Measure 1960;20:37-46.

14. Miettinen OS. Estimability and estimation in case-referent studies. Am J Epidemiol 1976;103:226 35.

15. Toelle BG, Peat JK, Salome CM, Mellis CM, Woolcock AJ Toward a definition of asthma for epidemiology. Am Rev Respir Dis 1992;146:633-7.

16. Dodge $R, B$ urrows $B$. The prevalence and incidence of asthma and asthmalike symptoms in a general sample. Am Rev Respir Dis 1980;122:567-75.

17. Torén K, Brisman J, Järvholm B. Asthma and asthma-like symptoms in adults assessed by questionnaires: a literature review. Chest 1993;104:600-8.

18. Anderson HR, Butland BK, Strachan DP. Trends in prevalence and severity of childhood asthma. Br Med J 1994;308: $1600-4$.

19. Davies GE, Thompson AV, Niewola Z, Burrows GE, Teasdale EL, Bird DJ, et al. Allergy to laboratory animals: a retrospective and a prospective study. Br J Ind Med 1983;40 $442-9$.

20. Torén K, Järvholm B, Sällsten G, Thiringer G. Respiratory symptoms and asthma among workers exposed to paper dust: a cohort study. Am J Ind Med 1994;26:489-96.

Received for publication: 4 April 1995 